\title{
慢性上顎筫炎手術後に發生せ万壤瘨性鼻炎に就て （所謂壞疽性鼻炎の本態に就いての私見）
}

日赤前橋支部病院耳兽咽晚科

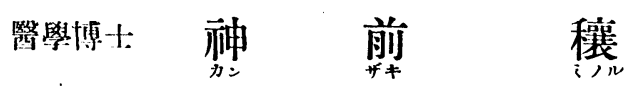

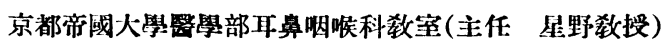

㝵修科生秦誠

\section{緒言}

慢性上顎竇炎根治手術は我耳悬咽喉科領域に。 於ては最も頻繁に行はる」手術の一つであるが， 日常餘りに無造作に行はれて居る本手術も化膿 䇴の根䋓を手術目的として居るのであるから， 手術中創面一の病源藏感染の危險及手術後創造 された倒而门の唯们鼻腔， 口腔等よりの病源菌

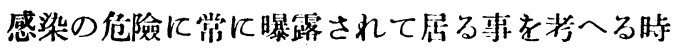
常に慎里なる態度で臨まなければならない事は 勿論であつて，稀ではあるが車篮なる合作朖の 發生が郝告されて居る。

余等与亦最近他䣽に化り慢性上顎筧炎根治手 衍を施行され壤应性悬炎を續弡し其の經過中州

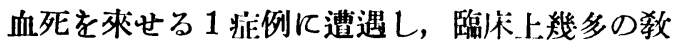
へられる點があつたので落に斯概要を述べ百に 所謂壞病性鼻炎の本態に就き最近の献告症例を

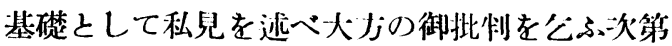
である・

\section{症例}

患者—某，28歲の男子，昭和12年:2月23日入院.

主訴 惡臭性奥汁を件ふ全身衰弱.

既往症, 家族歷 特記すべき事無し.

現病歷 患者は數件來鼻汁過多, 鼻閉塞を訴へ最近

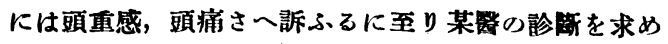

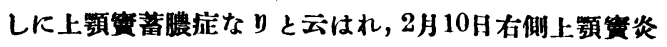

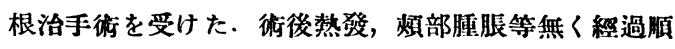
調なりしも術後 4 日目より右侧鼻汁漸次膿性と化し，

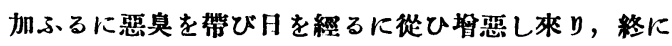
は㗀吅，胸內苦閜，食思不振と共に全身衰弱著しくな れる篇め 2 月23日本院に入院せり.

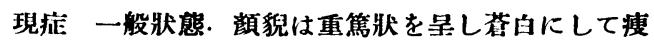
衰せり，脈搏は96，整調なるも緊張稍々不良で稍々頻 數を呈す。呼吸は 40 , 淺表なり. 體溫 $36.4^{\circ} \mathrm{C}$.

腐攻性口真著し，心畐心界共に正常，肺部に著變無

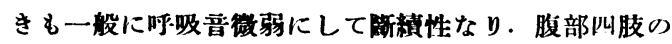
腱反射筫常なし. 企思全然缺乏し一般狀態不良なり（队 科久保图博士).

同所所見 右鼻腔は污栈帶綠色膿性分泌物を充滿し 之を除くに，下甲介は灰白赤色を是し前端部粘膜は大

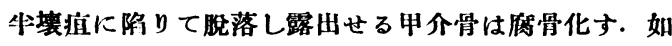

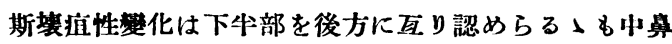
道に於て最も顯著にして自然孔附近では骨壁に披指頭 大の缺掑あり．中甲介も同樣の變化を呈し甲介骨前端

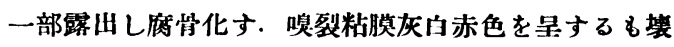
㨁性變化を認めず.

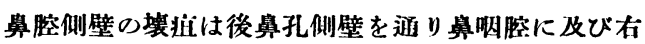

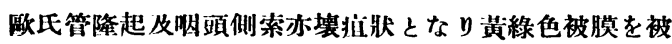
れり.

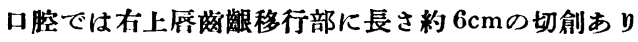
て多開す．犬蔌窝には略々圆形の直徑 $5 \mathrm{~cm} の$ 㢣開孔あ

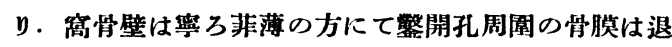
行性變化を呈せり．寡內は惡臭ある黃淥色の膿汁を无 湔す、之を排除し內部を精查するに管後壁山央は骨壁

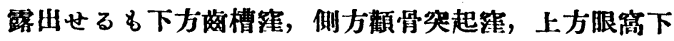
壁及び下鼻道側壁には灰白黄色の被膜を被れる貧血性

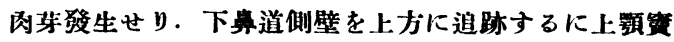


自然開口部附近に拇指頍大の骨缺摃ありてッ甲介及び 下甲介の一部を窥知さる。

尿檢查 蛋白 (陽性), 嗾 (陰性), レウロピリノーゲ ンフ(㓌性).

赤血球沈降速度 30 分 $30 ， 1$ 時間 $81 ， 2$ 時間 $103 ， 6$ 時 間 112 .

病源菌檢索 グフム㓌性の桿菌, 連鎖狀球菌及び葡 菊狀球菌を認めたり.

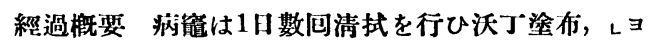
ードフォルムフ 末散布を行ふと共に $2 \%$ トリパフラ

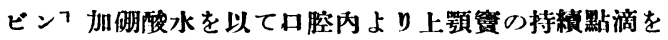
行一り.

全身的には輸血 $(1 \mathrm{H} 100 \mathrm{~g})$ ムロヂノン・リンゲル7液 (1 日 $1500 \mathrm{cc})$ เヴイタミンフC及び强心劑の注射を行一 v.

斯くて柆24日には口参大いに減じ其の後月を緦るに 從ひ鼻腔及竇內の所見も良好に轉じ食思出で來れり。

28 日午後 3 時所見では右咽頍側索部にある白苔部よ り僅か乍らす出血を認めたり. 然る處夕方重湯攝取後 家人之談話小午後 8 時牛笑然口腔及鼻腔より多量の鲜 血を排出し何等處置を施す㜊も無く遂に鬼籍に入れり。 其の出血量は $800 \mathrm{~g}$ 以上に及べり.

\section{考按}

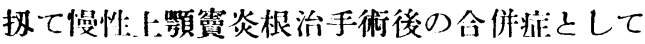
菖通一般に見られる考は軟部組織の反焦性:炎症

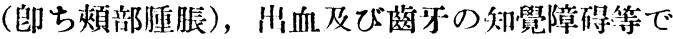
あるが之等の川出血は時に重等なる結果を招來 する事あるも他の者は暫特を經過して尋常に復 嘎するを常とする。

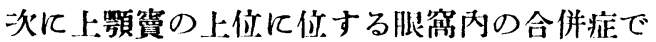
あるが單に上顎頕のみの根治手術の場合に續弡 する事は複合州副鼻腔根治手術若くは笠骨蜂炛 開放手術の際に比し稀である。

最も車管な經過を取る者は骨髓炎であつて， 手術後煩部の布痛性腫脹と熱管とを以つて始ま り骨膜下膿瘍形成と共飞骨髓の化膿性炎症は常 に侵潤性に進展し穈範なる腐骨を形成し, 時に 頭蓋內に進入し頭蓄內合併症を惹起する. 此の

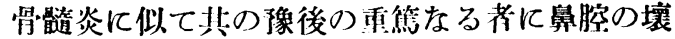
殂がある。

即ち本例に見る如く壞谊性宜炎を續墢する者 であるが，之を別個獨立の疢患と見るべきか， 或は骨篷炎の一異型と見做すべかに就いては 議論の有る處であるが茲には便官上壞盅性鼻炎 なる名棌を用ふる事とする。

壞㾞性鼻炎が士顎簤根治手術後に續發する事 は此較的稀で最近 6 年間僅かに 2 例の報告を見 るに過ざい(时中，滕归)。

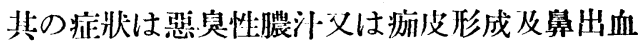

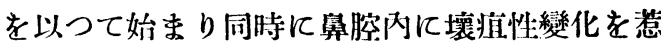
起する.之の變化は悬側壁の中甲介，下甲介凡 强く起り鼻中隔及鼻底を犯し更に後方鼻喵腔に 及び時に喉頭，氣管，氣管枝に迄及心゙事すらあ る(间中)。

壞谊の種類に就ては，余等の例では局所所見

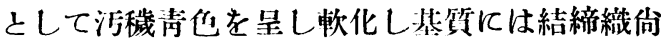

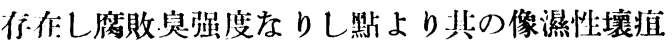

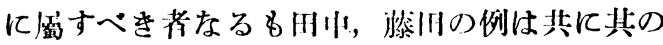
剀述阙明飞過ざ分明ならす。

其の豫後は全例を逝じ不良で夫ょ出血（神前，

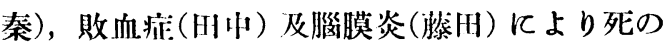
轉踣を取つてねる。

执て之が唀因としては (1) 病篦病源菌の傕出

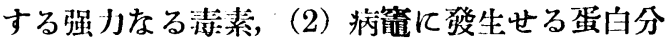
解醭素，（3）炎症の結果生じた血栓に上る㧓環 障碍等が舉げられてるる.

今余等の症例飞就き考察するに，悬腔の壇疽 は中鼻道に顯著で此の部に拇指頚大の骨缺損あ りし事，上顎贅の鼻腔との連緕は中鼻道骨缺損 部以外の部位に涊められなかつた事（郎ち本例 では下鼻道の對孔造設はなかつた）等から推察 
ナるに衍後上影筫內八分泌されし創液は充分に

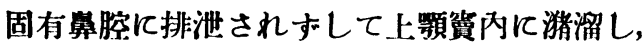
之が好適の病源菌培食基となりて茲に化膿性炎 症を意起し之より兴出されし强力なる表素及び 蛋白分解酳素と共に炎症により生じた血栓によ る循環障碍等の諸因子が加はりて中悬道を中心 とする壞瘨を弡生し更に淋巴道及血管の走行に 從ひて後鼻孔を越え舅咽腔に迄壞瘨を惹起せる 者と思惟さる.

其他に誘發因子として手術野の不完全なる消 毒, 手術の粗暴及患者の體質等も考虑さる」も

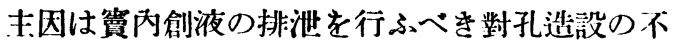
全に歸すべき者と思惟さる。

衍後創液の誘導不完全なりし第め種々の合作 症の續發を見るは副悬腔特に前額筧手術に於て ப゙あるが，上顎筫根治手術に際しても本例の如 き重箵なる合作症を緢發する事あるに鑑み余等 は茹に更めて完全なる對孔造設の必倠なる事を 强調し度い. 此の意味に於ては下鼻道に造設せ る對孔さへ稍々もすれば狹突され易い傾向にあ るを以つて對孔を中宜道に求むる術式の害施に 當りては，熟練の上ならでは所期の目的を蓬す

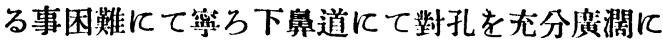
造設するを得策とする.

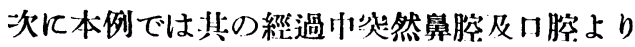
多量の動脈性将血を來し遂に之が致命的となっ た・此の川血は動脈血にて短時䦌に敬めて多量 なりし事より動脈血管の破裂に依る者なる事は 明なるも其の部位に就き些か侤察して見度い. 病䇫附近の分布血管は大繒次の如き者が考へ らる.

1. 蝴蝶口蓋動脈(外影動脈の終末枝)は蝴蝶
口蓋孔を出て後方より䀠腔に分有し其の第 1 枝 たる後算動脈は睤腔側壁殊に中甲介，下甲介に 大なる枝を送る。

2.上顎䔈後壁裏には內顎動脈の走行あり.

3. 前及後篩骨動脈(內頸動脈よりの分枝)は 節狀板を鿓いて鼻腔側壁上部に至る。

4.上咽頭動脈(外頸動脈上りの分枝)からは 吆頭枝を舅咽腔側壁及歐氏管に出す。

本例では壞疽病戀は悬腔側壁特に川悬道を中 心とし中甲介，下甲介の淋巴及血管の走行に沿 ひて後方鼻咽腔側壁の歐氏管隆起飞迄及べる事 及び出血掌门悬咽腔側壁の壤㾝部より僅か乍ら 出血を胃た事等より考へるに，蝴蝶口菲動脈又 は、咽嘼動脈の破裂が考へられるが，北の出 は短時閒に致命的多量なりし事より考へると深 部の更に大なる血管即ち內頸動脈よりの川血を 思考さる」も剖檢の汻されさりしため之が部位 の確定し得さりしは遗憾なり。

以上簡單作ら余等の經驗せる上䫑筫根治手術 後に續發せし壤疽性鼻炎に就き其の進展經過を 述へ之が發生原团に關し聊か考察を加へたり。

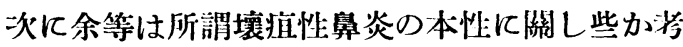
祭を加へて見度い。

\section{所謂壤疸性鼻炎に就て。}

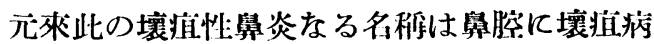
継の發生せる際に肘ふる症狀的名稱にして，其 の原因に至りては斯く單一な者でない．余等は 之に興味を覺え最近 6 年間の任告例を拾集し之 を基礎として本疾患に就き聊か考察を加へて見 度い. 茲には其原因の明確なる結核，徽毒，瀨 及条種急性傳染病に依る者は除外した。 


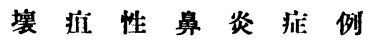

\begin{tabular}{|c|c|c|c|c|c|c|c|c|c|c|c|c|}
\hline & 却化 & 年 & & & 㫌 & & 狀 & & & $\begin{array}{l}\nabla \\
\mathbb{E}\end{array}$ & $\begin{array}{l}\text { 試 } \\
\text { 驗 }\end{array}$ & 轉 \\
\hline & 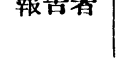 & 齡 & 性 & 因 & 甲 介 & 中隔 & 其 他 & 治 療 起 㨁 & 起茨囷 & 反 & 妢 & 咳 \\
\hline 1 & 俣 野 & 23 & $\delta$ & 不 明 & 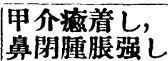 & 穿孔 & $\begin{array}{l}\text { 口蓋の埣 } \\
\text { 疽を來す }\end{array}$ & 䮤 徽 療 法 & டデา菌（？) & $(-)^{3}$ & $\mid$ & 死 \\
\hline 2 & 四川 & 21 & 우 & 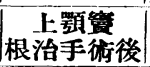 & 萎縮 と壊死 & 穿孔 & $\begin{array}{l}\text { 㫿頭, 氣 } \\
\text { 管に及ぶ }\end{array}$ & & $(-)$ & & 同上 & 死 \\
\hline 3 & 藤 门 & 49 & $\hat{o}$ & 根治手術後 & $\begin{array}{l}\text { 少甲介，下 } \\
\text { 甲介坥庭 }\end{array}$ & 壊瘨 & $\begin{array}{l}\text { 鼻咽腔K } \\
\text { 及出 }\end{array}$ & $\begin{array}{lll}\text { 画 微 } & \text { 潦 } \\
\text { 㴬 } \\
\end{array}$ & $(-)$ & $(-)$ & 同上 & 死 \\
\hline 4 & $"$ & 26 & $\hat{o}$ & 不 明 & 增 庭 & 壤瘨 & 啒頭に及る゙ & & $(-)$ & $(-)$ & 同上 & 死 \\
\hline 5 & 森 本 & 33 & ㅇ & 不 时 & 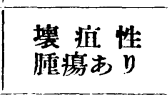 & & 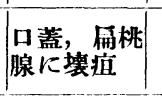 & 腫湯摘出術 & 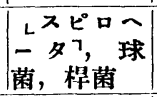 & & $\mid$\begin{tabular}{|l|} 
臬 \\
芽 \\
\end{tabular} & 死 \\
\hline 6 & 舟 山 & 40 & 우 & 不 明 & & \begin{tabular}{|l|} 
基底け \\
溃儫
\end{tabular} & 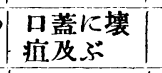 & & 抗酸性菌 & $(-\infty)$ & $\mid$ & 不明 \\
\hline 7 & 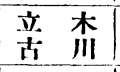 & 52 & $\hat{\delta}$ & 不 明 & 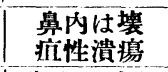 & & 外鼻に及3゙ & （剖檢で肉腫） & & & & 死 \\
\hline 8 & 柴 保 & 38 & $\hat{\delta}$ & 外 傷 & $\begin{array}{l}\text { 鼻內は㱛ど } \\
\text { 全部溃場 }\end{array}$ & & & 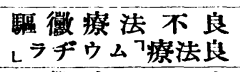 & & $(-)$ & & 沿 \\
\hline 9 & 吉南 闻 & 26 & $\hat{\jmath}$ & 不 㺫 & $\begin{array}{l}\text { 下畑介霄 } \\
\text { 一部殘る }\end{array}$ & 穿孔 & 外鼻に及ぶ & $\begin{array}{l}\text { 㠗徽療法不良 } \\
\underline{\underline{a}} \text { 線照射良 }\end{array}$ & 球菌, 棍菌 & $(-1)$ & 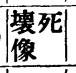 & 治 \\
\hline 10 & 神前, 秦 & 28 & $\hat{\delta}$ & 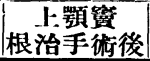 & 壊 & & $\begin{array}{l}\text { 鼻咽腔K } \\
\text { 及絮 }\end{array}$ & 鐱血, 局所清拭 & 球菌, 桯菌 & & 同上 & 死 \\
\hline
\end{tabular}

壤瘨性算炎症例10例を總括し法人は次の事を 知る.

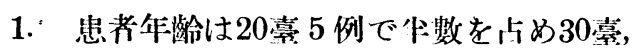
40豪夫љ 2 例，50辜は 1 例である.

2. 性别では可性 7 例で過作数を占め久性は 僅か 3 例に過ぎない。

3. 原因の明碓なのは测罢腔根治手術後の 3 例, 外偤による1例で他は不明である.

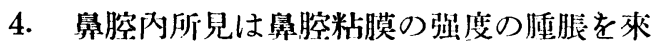
せる者 1 例, 肉芽腫の像を呈せる 1 例を除き他

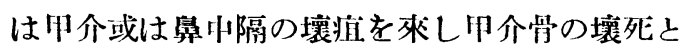

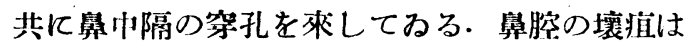
更に進展し外舅に及一方者 2 例，口蓋へ波及世 るもの 3 例，鼻呐腔に必べる者 4 例で更に喉頭 に迄波及せる者 1 例，氣管，氣复枝に迄及べ 者 1 例あり。

5. 血液のワ氏反應は 6 例で陰性, 他の 4 例 は不明なり。

6. 病䉭より檢出せる細菌はしスピロへータา
(1例)，桿菌(4例)，球菌(3例)， しヂフ菌(？) (1 例)，挄酸性菌(1例) で特别の病源菌は確認され てみない.

7. 組䄉學的には 1 例淋巨肉輩腯の像を呈せ るも他の 7 例にては單に壞死の像を是せり.

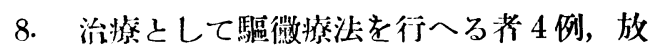
線㟫法老行へる萑 3 例あり. 此の內放線療法を 行へる 2 例は治涾よてる.

9. 轉歸は死亡 7 例, 治瘾 2 例, 不明 1 例で ある。

10. 剖憸を行へる 1 例で肉腫を證羽してる.

以上を通覽すると其の原网の明暌なるは 4 例 で此の内 3 例は上顎䁇根治手術後に發生せる者 である.

他の 6 例に就ては誘肉として何等認むべき者 が無い. 然し剖憸により肉腄を認めた 1 例ある のと治癒せる 2 例は放線療法を行へる者なる事 等より考察するに本疾患は肉腫其他の惡性腫瘍 と何等かの關係があるのではないかと思惟され 
・る. 換言すれば組織學的に未だ惡性腫瘍なる事 の證明されさると先立ち局所に壞疽の發生を見 るのではないかと思惟さる。

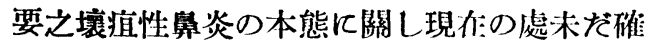
定的の域に達せす份將來に俟つべきであるが其 の內誘因の明かな外賃性の大半は上顎凟根治手 術後に發生せり。

茲飞余等の 1 例を追加し將來の㦄考儿資せん 之す.

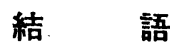

1. 本例は28藏の男子にして存側上䫑筫根治 手術後壞疽性鼻炎を續發し出血死を桃せる者な b.

2. 本例に見を壞病性鼻炎の上:なる誘因は上 顎筫內分泌液の排泄不全几低る者之思惟さる。

3. 余等は茲に更めて上類筫根治手術に際し 十分なる對孔を造設すべをを强調す。

4. 更に余等は所謂壞谊性悬炎の本態に就 論及したり。

㨄筆するに常り恩阨星野教授の御校閶を深謝与。

主要文 能

1) Katz: Handbuch d. sp. chirurgie d. oberen Luftweg. Bd. 3.

俣里：大日耳鼻，44焱.

阿久根：大日耳年. 45 卷.

午山：大日耳鼻. 46 卷.

12）淿：外科樬論.
2) 田中：大日耳鼻, 43 卷.

5) 叞田：大日耳鼻, 45兊.

8）立木：大日耳鼻，45焱.

11) Ostmann: Ztschr. f. Lary. $21 \mathrm{Bd}$.

\section{鼻咽腔しヂテリーフに就て}

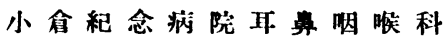
圤鸽茂 郎
荒杰新

緒言

耳鼻呕喉科領域に於て，上氧道しヂフテリー は現今醫學上の冬力面上り最も上く政究された る疾患の一なれど，上氧道川鼻咽腔の程患率は 諸氏の統計を見ると韩れも最も低率を示し，特 几算咽腔に限局せるしヂフテリーフの症例報告は 誠に察ふたるるのなり。

斯かる現象は如何なる原凶に基くものなるや 郎ち鼻腔, 咽頭及び喉頭に比し鼻咽腔は しヂフ テリーフ 菌の感染する事尠きか, 或は又賽際臨
优上此部は他部に比し檢查困難なる第盾過され 易き第なるか疑間の仿する所なり。

余等は最近鼻咐腔に限局せるしヂフテリーフの 3 例に遭遇せるを以て，茲江其大栐を報告し諸 家の教示を乤はんとす。

\section{症例}

第 1 例 18 荿, 男, 昭和16年7月15日初診.

家族歷, 既往歷 其々特記すべきものなし。

现病歷，現症並に經過概略 昭和16年 7 月 18 日，雨

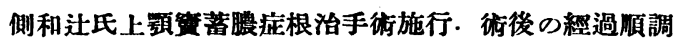

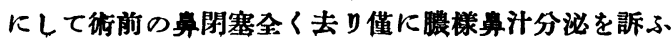

